\title{
Book Review: Emmanuel Todd, Who is Charlie? Xenophobia and the New Middle Class
}

\section{Tina Goldschmidt}

[Post-print version of Goldschmidt T (2017) Book Review: Emmanuel Todd, Who is Charlie? Xenophobia and the New Middle Class. International Sociology 32(2): 240-243.]

On January 10 and 11, 2015, following a violent attack on the Paris offices of the satirical magazine Charlie Hebdo, citizens and political leaders embarked upon large-scale rallies in various French cities. Under the motto Je suis Charlie (I am Charlie), these 'republican marches' were intended as a show of solidarity with the universal human right to freedom of expression, enshrined in the Jacobian value trinity of liberty, equality, and fraternity at the heart of the French Republic. In his book Who is Charlie?, Emmanuel Todd takes issue with this standard portrayal of events. Condensed in a swift 200-page essay, the author argues that the republican marches were not advocating the universal right to freedom of speech but rather betrayed a salient racism and Islamophobia that is spreading throughout France and the West.

It used to be a widely held notion that satire was a tool of the powerless, designed to 'expose the injustice, blindness and hypocrisy of the powerful' (Juss, 2015: 41). Yet Charlie Hebdo persistently targets Muslims, an internally diverse but widely marginalized, socioeconomically disadvantaged subgroup of French society. In the days and months following the tragic attacks on the magazine's headquarters, those condemning the violence that had occurred but criticizing the way in which Charlie Hebdo tended to portray Muslim religious symbols were discredited as supporting terrorism and blaming the victims. Those who were not Charlie were in league with the 'other,' the terrorists' side, which was part of an imagined Muslim community. Todd describes this new dichotomization as one of the defining lines of what he calls 'neo-republicanism' - a demand for unanimity in secularism, in essence, requiring Muslims to 'stop being Muslims' and critics of any couleur to toe the line of what the majority regards worth uttering so as prove their belief in freedom of speech.

It is because of these commonplace dichotomies of good and evil, Charlies and terrorists, that Todd speaks of a France, a Western world in fact, in which freedom of speech is not a universal right, but the prerogative of the upper and middle classes, who as of yet remain unscathed by the ongoing economic crisis and intent on protecting their beliefs and way of life. In equating freedom of speech with the duty to ridicule the religious figure of a marginalized minority, the republican marches and their aftermath had turned satire into a tool of the powerful. According to Todd, the attacks on Charlie Hebdo provided these advantaged social strata with an opportunity to reaffirm their way of life and its underlying ideology of austerity, free trade, and general pro-Europeanism that leaves the lower classes behind. The fact that Europe is persistently caught in a state of crisis despite its ideological immovability leaves the upper and middle classes caught in a quasi-religious crisis of 
meaning and direction. In this state of crisis, Islam appears as the ideal scapegoat, with its members discernibly different and overrepresented among the society's weakest.

Todd's book provides us with important insights on the racialization of freedom of speech as a seemingly universal value across modern democracies. The term racialization describes a process by which matters of legitimate membership and belonging are recast along ethnic or racial dividing lines. Research in the United States and various European contexts alike has, for instance, shown that majority perceptions of who should be allowed to benefit from the welfare state (or belong to the welfare community) are racialized, with blacks in the United States and non-Western immigrants in Europe being persistently ranked among the least deserving beneficiaries (see e.g., Faist, 1995; Gilens, 2000; van Oorschot, 2006). In this way, racialized perceptions of legitimacy - in the case of Charlie, to express one's views freely - are often regarded to be symptomatic of a symbolic, covert kind of racism that may even escape individual consciousness. Todd does this work of uncovering racialization following a laudable research agenda that should provide food for thought beyond the topical premises of this book. As social scientists, we need to 'disclose . . . the values latent in political action,' to uncover what might lie beneath apparent value neutrality (p. 140). Pursuing this objective, Todd does not focus on the usual right-wing suspects when it comes to racial biases or even outright hatred. He also takes a close look at the political left. Although the French Socialist Party talks about integration, its ardent defense of a multicultural 'right to difference' leads it to choose de facto segregation. Doing so, the party betrays a kind of differentialist, objective xenophobia that does not even consider that all men might in fact be created equal and maintains its belief in innate (cultural) difference even in the face of contrary evidence. Supporters of France's right-wing populist National Front (NF), on the other hand, are driven by a different kind of universalist xenophobia, believing that everyone should be equal in terms of their adherence to French majority values, deeming those who seemingly do not 'non-human.' Their xenophobia is, however, subjectivist, as it is easily affected by personal experience, as is evident in the frequent partnering of former NF supporters with men and women of foreign descent. Both types of xenophobia interact in a vicious cycle: policies advanced by the Socialist Party are driven by an (unconscious) objective xenophobia that acknowledges and reinforces differences, which in turn foster the subjective xenophobia of the NF and its supporters. Giving rise to a 'mixed but still very menacing form of racism' (p. 144), subconscious processes like the one described are of enormous importance to our understanding of society. Studying them is extremely difficult, yet still constitutes one of the main contributions sociology can make as an academic discipline. In the face of the counterintuitive wave of thought censorship growing from the $I$ am Charlie solidarity movement, Todd's contribution makes this blatantly clear.

As laudable as Todd's quest to expose covert xenophobia is, the book loses its persuasive power when it turns to explaining xenophobia's root causes. As in his earlier works, Todd holds that latent anthropological variables, traditional family structures, and religion in particular, provide 'access to the unconscious of peoples and their leaders' ( $\mathrm{p}$. 113). Regions' religious past, Todd argues, shapes how individuals view relationships among family members and, by extension, among actors in society at large as either equal or unequal and marked by either liberty or authority. The traces of abandoned Catholicism ('ZombieCatholicism') and traditionally hierarchical, authoritarian family structures of France's 
peripheral regions explain why out-group hostility is on the rise and spreading from these areas into la France central, which finds its culture of equality too weakened and disorganized to withstand.

Todd himself admits that his theoretical model is not easy to accept. Indeed, although it is certainly valuable to consider present-day conditions in their historical context, Todd's anthropological framework does not fit the case of French and European xenophobia in many instances discussed in the book. For example, in attempting to show how ZombieCatholicism is the culprit of xenophobic outpourings across Europe, Todd discusses the German debate on circumcision and reports that one of its greatest opponents in the European Parliament stems from the traditionally Catholic region of Bavaria. However, the question of whether the religiously motivated circumcision of young boys should be prohibited (a policy mainly affecting Muslims and Jews in Germany) was not restricted to the country's presently or formerly Catholic regions, with strong proponent voices throughout the German public sphere. To take account of this, Todd argues that 'Zombie-Protestantism' might be an explanatory factor, which, however, undermines his arguments about how France's secular or formerly Protestant regions differ from Zombie-Catholic ones.

The list of examples slightly bent to match the theory could be extended. Todd explicitly states that the book is not academic in tone. Yet, in supplementing his illuminating descriptive report of what happened but was not seen by many in January 2015 with a grand explanatory theory, supported by aggregate-level correlation coefficients relating often sweepingly defined variables, he makes it unclear which audience this book seeks to reach. As a purely academic publication, the theoretical framework would have required adjustment and the statistical representation of regional differences more formal work. Yet as a piece of public sociology, providing a removed, objective interpretation of things that were said and done in a period of 'collective hysteria,' the book would have been much more convincing had it stayed at the level of thick description. Rather than focusing on making theory work, the story would have benefited from a detailed discussion of the actual thematic bias of the magazine Charlie Hebdo. In particular, a visual analysis of cover caricatures published by the magazine would have been desirable to show whether Muslims were indeed more often the target of Charlie Hebdo's satire than other religious and political groups and also in which way they tended to be portrayed. As it stands, Todd does little to convince the doubtful reader that the basic premise of his argument is correct, that the republican marches did indeed not proclaim freedom of expression as a neutral value for all but as a duty to blaspheme and defend an imagined past of 'secular homogeneity.' Yet, even as it stands, the book provides an abundance of courageously uncomfortable observations, offering an alternative narrative that leads the reader to question whether what is called universal might not in fact presume some to be more equal than others. 


\section{Author biography}

Tina Goldschmidt is a doctoral candidate in sociology at Stockholm University and is currently a visiting researcher at the Wissenschaftszentrum Berlin. Her research explores the consequences of international immigration for intergroup relations in Europe. Having a keen interest in the welfare state, she explores changing notions of belonging and deservedness.

Address: Stockholm University, Department of Sociology, 10691 Stockholm, Sweden. Email: tina.goldschmidt@ sociology.su.se

\section{References}

Faist T (1995) Ethnicization and racialization of welfare-state politics in Germany and the USA. Ethnic and Racial Studies 18(2): 219-250.

Gilens M (2000) Why Americans Hate Welfare: Race, Media, and the Politics of Antipoverty Policy. Chicago: University of Chicago Press.

Juss S (2015) Burqa-bashing and the Charlie Hebdo cartoons. King's Law Journal 26(1): 2743.

Van Oorschot W (2006) Making the difference in social Europe: Deservingness perceptions among citizens of European welfare states. Journal of European Social Policy 16(1): $23-42$ 